\title{
Stimulate Students' Interest by Genetics Exordium Teaching
}

\author{
Yan Li \\ Biology Department, Dezhou University \\ Dezhou 253023, Shandong province, China \\ Tel: 86-534-898-2127Ｅ-mail : lylxy0524@126.com
}

\begin{abstract}
Genetics is the important specialized course of bioscience and whether exordium is taught wonderfully or not plays the important and pivotal role. Well teaching exordium class may stimulate students' deep interest and intense desire for knowledge in this class. This text, according to teaching experience and taste, puts forward several teaching measures about genetics exordium class.
\end{abstract}

Keywords: Stimulate, Genetics exordium, Teaching

\section{Introduction}

Genetics is one of important biology basic courses, it is very important to many other subjects, and it develops quickly with the appearance of new knowledge and new technology. The molecular genetics field develops more quickly. However, many students are terrified by the sight of the subject because it is a specialized course with abstract and difficult knowledge. Well then, how to inspire the students' learning interests and make the students enter into genetics world full of confidence and enthusiasm? One good introductory class is the key for students to open the door of genetics. Exordium is the outset of one subject and also the reduction of one subject and the part that explains the whole text's major idea and contents and so on. Seen apparently, introductory class is easy to teach and students may understand it, so that the teachers will not pay attention to it and only repeat what the books say and mention lightly. However, in the course of teaching, the penman deeply realize the importance of well teaching introductory class, because whether the introductory class is taught wonderfully or not immediately concerns the students having leaning interests and intense desire for knowledge or not to this subject, and plays an important roll for the students well learning the subject or not. To the teachers, if the teaching contents of introductory class are abundant, with picturesque language, close to our real life and full of enthusiasm, he can firmly attract his students to his teaching and build good foundation for his future teaching work. To the students, the teaching value of introductory class mainly lets the students well prepare for the genetics.

Genetics is one of the important professional courses for the students who major in biology in the universities and colleges and has an important meaning for the students' leaning of further courses and employment. But most of the students do not attach importance to the leaning of introductory class and consider that the introductory class only teaches the professional history and developing direction and are not involved with the practical theoretical knowledge. Actually, the introductory class of one subject is very important and it not only teaches the students the main research contents of this subject, but also makes the students preliminary understand the twists and turns on the scientific development, so that it inspires the students' learning interest and the ideality of the students dedicating to science. Therefore, introductory class combines science, knowledge, interest and imparting knowledge and educating people in performance. Well teaching introductory class, the teachers not only have sound professional knowledge and but also have encyclopedical history of science knowledge and scientific philosophical thought. Thereby, how to well teach the introductory class of genetics deserves each genetics teacher to strive and explore. After many years' practice of genetics teaching, the penman considers that the introductory class is well taught from the flowing aspects.

\section{Understand the having-studied courses and teach the students with students' having learned knowledge}

Understanding the students' having learned knowledge and introducing the genetics knowledge on the basis of students' having learned knowledge, the teachers make the new knowledge and old knowledge well linking and fuse and also make the students more comfortable enter the learning of new knowledge. For example, the teachers simple retrospect the having learned types A, B and O system knowledge in physiology, and then introduce the decisive role of gene to blood type and the correlation between genes of deciding types A, B and $\mathrm{O}$ system and the genes of other blood types. For instance again, the students have learned that sickle cell anaemia is because one amino acid on the polypeptide chain forming hemoglobin is replaced by another different amino acid in nature, however what is the essential reason? It is as a result of genetic change. How the gene is changed? What is the difference of genetic phenotype in different 
conditions (under the condition of enough oxygen and absence of oxygen)? By reviewing the old knowledge to introduce the new knowledge makes the students eliminate strange feeling and accordingly makes the students, to follow as a matter of course, have familiar feeling to the new knowledge which is to learn and at the same time full of the design for studying.

\section{Elaborately design and inspire the students' learning interest}

To the exordium of new subject, the teachers must elaborately design and consequently obtain reasonable teaching effect and lay the groundwork of the future teaching. To the teaching of introductory class of genetics, the teachers introduce it from the students' familiar genetic phenomena and make them deeply think about the nature and reason of these genetic phenomena and consequently inspire students' interest to genetics. For example the reason of hen's crow phenomena, the teachers may let the students to answer whether this phenomena is relevant to genetic substances; for instance the teachers may preliminary introduce the knowledge of gender self regulation of bee swarm and the bearing ability of female bees, so that the teachers guide the students to think about the inner reasons and give mouth to the relation between this phenomena and genetics; for example the relation between corm gender and gene also makes the students have interest to genetic reason. Where there id interest, there is momentum. It has an important meaning to express the born hidebound scientific knowledge through simple and interest measures and to give play to thinking initiative of the students to the subsequent learning of genetics.

Teaching language is the language that is used in the teaching courses by the teachers, and it is both the carrier of transferring knowledge and information and the model of forming and improving the students' language cultivation. The good teaching language not only accurately and clearly transfers the teaching information and makes the knowledge inpour into the students' heart like a delicate water fall, but also livens up classroom atmosphere and inspires the students' learning interest; on the contrary, old-fashioned, bald and dull language will make the students drowsy and lacking in interest and even the teachers themselves feel distasteful (Wu and Bai, 2007). The partial contents of genetics exordium are very abstract and difficult for students to understand, and at this time the teachers should use vivid language to help and school the students to apprehend and absorb the knowledge. When teaching the exordium, the teachers may put forward the doubt that accords with the students' psychology to arouse the students' interest. Through these vivid language boost up the cognition to genetic substance and produces the dense interest to genetics.

The students are the main body of learning and the teachers are the aid and promoter in the course of students learning. The reasonable measures sometimes gain the effect of getting twice the result with half the effort. Therefore, the teachers still introduce the measures of learning genetics in the exordium of genetics course and show clearly the approach of well learning the genetics for the students and make a fine start to their future teaching work.

\section{Define the research subject and task of genetics}

Any of the subjects has its own research subject and the premise of separate subject. Genetics is one abstract subject referring to life origin and biological evolution and is also the basic science closely integrating with practice and it directly guides medicine research and the breeding of vegetables, animals and microorganism. In the objects of the microorganism (bacilli, epiphyte and virus), vegetables, animals and human being, it researches their rule of heredity and variation. The task is to clarify biological genetics and variation phenomena and to guide the breeding of vegetables and animals and microorganism and to improve the medical standard. Defining the research target and task of genetics makes the students have a definite aim to learn genetics, so that the students may sort out my thoughts and be favorable for receiving the new course and forming their owns' learning measures.

\section{Teach the developing history and inspire the students' learning passions and make the students gain revelation.}

Genetics is one subject of researching the basic property and disciplinary of life and has the close relation with industrial and agricultural production and becomes the pervasive object of each subjects, so that thought is very active in this research field and all points and genres are always existing (H. Stubbe, 1981). Genetics history is one subject history of science history and is the history of researching the objective laws of inheritance and variance and changing biological properties by using discipline. In the international genetics convention held in Ontario in 1988, the chairman of the convention, Prof. R. H. Hayne s said that: "genetics is the throat and heart of nature history" (Wang, 1998). Looking back the evolvement of each theoretical hypothesis in the history of genetics history, the reasons are analyzed from thoughts and measures, which is very meaningful to train the scientific and technological qualities of the students.

G. Mendel, the Austria scientists, through pea cross experiment, published "vegetable cross experiment" and put forward the concept of genetic factor and discovered regularity of segregation and law of independent assortment in 1866. But then, till 1900, Mendel established the segregation principle and independent allocation method was rediscovered, so that the year of 1900 was ordered as the genetics naissance year and Mendel was honored as "the father of genetics" and genetics was more than one hundred year from naissance. The reason for Mendel discovering the two basic laws of genetics and having the ability to surpass predecessors and science was that he had splendid scientific 
research ability and quality. Mendel's successful reason rested with him choosing the appropriate experiment materials and exercising statistics methods and simplifying the research problems; at the same time, in experiment, Mendel was serious in attitude and fertile in practicality. In order to assure the exact experiment result, Mendel carried through many times repeated tests almost eight years later and he also carefully observed and recorded the synoptic change and variance phenomena. He was talent experimenters (Yang and Zhu, 1995). There were many revelations from Mendel experiment.

In 1910, T. Morgan published the first gene localization thesis and discovered gene linkage exchange phenomena in 1911, paving the way for chromosome heredity theory. In the following 15 years, Morgan and his students H. J. Muller, A. H. Sturtevant and C. B.Bridge s carried through sets of wonderful experiments, especially had the new thoughts combining the recombination value of linkage gene with the distance on the chromosome, which was the very splendid fruits for biology research. The work of each scientist in Morgan experiment was closely linked and relatively independent. Muller was adept at designing exact experiment; Bridge s was splendid cytologist and very sensitive to subtle change of chromosome structure; the strong point of Sturtevant was mathematics and statistics; Morgan was the tutor and the academic leader of analyzing results, putting forward problems and confirming the main attack. The scientists who had complementary capability and consistent aims gathered together and formed "fist" and made great contribution to the development of genetics (Fu, 1987). Many years later, Sturtevant remembered that: "this collectivity was a whole and each person did his own experiment, however they each other quietly understood the research progress. Each research fruit was freely discussed and they were never caring for whom initially putting forward the new thought and design, hypothesis and explanation. What they were caring for was how to promote the work. They had too many work to do and thoughts to validate and technology to develop and establish. The experiment that was so harmony and stirring was not common at that time (Gao, 2002)." Morgan also originated publication and edited books and made the genetics research tend towards systematization, theorization and signification, which indicated that the research of genetics theory came into new stage. At the same time, Morgan attracted the talents and absorbed large numbers of excellent researchers who made great contribution to the development of genetics. Morgan considered that the scientists not merely compete with each other but also communicate with each other. Morgan was very modest and the 100-compatible thoughts and responsibilities of cultivating scientific talents advocated by him was still meaningful to the researchers who were engaged in biological science.

Many scientists had once considered the question: "why the person that discovered DNA double helix structure was F. Crick and J. D. Watson? One of them was struggling for writing doctoral dissertation and another was merely 25 old. Why R. Frankelin who owned x-ray diffractions photo did not discover it, however Crick and Watson made a great coup after watching her photos? Why L. Pauling who had deeply studied the structure and barely illustrated protein helix structure was left behind in this competition?" Looking back the developing history of DNA double helix, the following aspects had the educational meaning: the benign quality and successful cooperation; informative news and occupying the important materials; correct thought and the methods of using science. PCR technology was designed according to the characteristics of DNA duplication and the quickly expanded special DNA sequence in the exterior and was widely used in all the fields of gene research, so that was honored revolutionary technological breakthroughs in the fields of molecular biology. The PCR technological principle was simple and why Mullis thought of it? K. B. Mullis who discovered PCR technology was a legendary figure in science history and deep mathematical foundations made Mullis's thought very sharp; self - education made him free of inherent thought pattern; the three aspects, such as making a showy display of one's abilities and daring to achieve his own thoughts and regardless of someone else evaluation, made Mullis bold enough to make his own work. The integration of the three aspects apparently answered the doubt of many people (Chen, 2002). Thus it can be seen, the scientists who made great contribution to the scientific development had their own special scientific thoughts and opinions. These thoughts were seen at the scientists' thought, understanding and cognition in his research field and his explanation to the creative work.

Through introducing these examples, they can school and inspire the students rising in great vigor and the glory of his country. The aspects that may enlighten and inspire the students, inspire their dense interest to genetics and even produce the beautiful wish of engaging in the genetics research, were their profound knowledge and insight and the spirits and noble qualities of bravely practicing, regularly thinking, dedicating to the humans.

\section{Integrating with reality and emphasizing the application of genetics}

The contents on the status and the developing foreground of genetics in the genetics exordium refer to hot topics and binding problem in the field of genetics research. Genetics is the basic science of life science and is closely related to the development of agriculture, forestry, animal husbandry, fishing, industry fermentation, medical care, pharmacy and national defenses and embodies the relation between theory and industrial practice. The national rice achieved the "three-line" matching in 1973; for the first time, indica hybrid rice was developed in the world and the transformed variety including corn, soybean, cole and potato were planted in large areas. At present, the research that transforms the human gene to pig made great contribution to cross species organ transplantation; the research to transgenic mice had 
the important meaning to cure some genetic diseases. The genetics has a very close correlation with pharmaceuticals, and the pathogeny of many frequently-occurring diseases, such as transmissibility diseases, knub, high blood pressure, asthma and diabetes, are genetically related. The research result of objective gene treatment, antisense RNA technology, RNA interference etc. treatments shows great future. Genetics has a very close relation with society and law, such as the influence of pollution to gene and chromosome and paternity testing and so on.

Before the students learn the genetic knowledge, explaining the hot topics of genetics research should emphasize particularly on the exordium of examples. On the lecture of art, completely using advantages of lively simile and multimedia teaching inspires the students' curiosity and thirst. With the aid of multimedia teaching excellent in both pictures and texts characteristics, the teachers exhibits the operation of genetically modified organisms and the naissance process of Dolly, the cloned sheep etc. contents to the students. In a word, the teachers should try the best to avoid the explanation of profound theory and emphasize particularly on the practicability and interesting. In the class of genetics exordium, the teachers should teach the relation between genetics and industrial and agricultural production and make the students definite the important meaning of well learning genetics, such as the purposes of learning genetics, tasks and meaning, encourage the students to well learn the genetics and to reach the anticipative teaching effect.

In conclusion, the teaching of genetics exordium opens up another door to the field of life science to the students. However, the teaching that in deed does this and brings the students to the sea of life science knowledge is not an easy thing. It not only requires that each teacher exercises the mind and explores the effective teaching methods, but also requires that each teacher continuously improve his own qualities, enrich his own learning and understand the hot topics of genetics development and research. As the saying goes, good beginning is half done, and because the genetics exordium as the first class for students to contact genetics, its function is self-explanatory. If the teachers make the students definitude study object and contents and inspire their learning interest to genetics, it will be very helpful to their future teaching work.

\section{References}

Chen, R. X. (2002). Decrypt the Code of Life Science-the Nobel Prize and Genetics. Whuan: Wuhan Publishing House.

Fu, J. L. (1987). Exordium of the Genetic Analysis. Chengdu: Sichuan Science and Technology Press.

Gao, Y. Zh. (2002). Morgan and the chromosome theory of inheritance. Hereditas (Beijing). 24: 459-462.

Stubbe, H. (1981). History of Genetics from Prehistoric Times to the Rediscovery of Mendel's Laws. Shanghai: Shanghai Science and Technology Press.

Wang, X. M. (1998). Explorations Into Genetics in Broadened Sense. Wuhuan: Wuhan University Press.

Wu, P. \& Bai, Zh. (2007). Experiences of Using Teaching Language in Classroom. Journal of Kunming Medical College. 28: 226-229.

Yang, X. R. \& Zhu, Y. G. (1995). The History of Genetics. Wuhuan: Wuhan University Press. 